Finding of No Significant Impact

for the

Waste Segregation Facility

at the Savannah River Site

Agency: U.S. Department of Energy

RECEIVED

FEB 271998

Action: $\quad$ Finding of No Significant Impact

Summary: The Department of Energy (DOE) has prepared an environmental assessment (EA) (DOE/EA-1229) for the proposed construction, operation and decontamination and decommissioning (D\&D) of the Waste Segregation Facility (WSF) for the sorting, shredding, and compaction of low-level radioactive waste (LLW) on the Savannah River Site (SRS), near Aiken, South Carolina. Based on the analyses in the EA, DOE has determined that the proposed action is not a major Federal action significantly affecting the quality of the human environment within the meaning of the National Environmental Policy Act (NEPA) of 1969. Therefore, the preparation of an environmental impact statement (EIS) is not required, and DOE is issuing this Finding of No Significant Impact (FONSI).

Public Availability: Copies of the EA and FONSI or further information on the DOE NEPA process are available from:

Andrew R. Grainger

NEPA Compliance Officer

Savannah River Operations Office

773-42A, rm 212

Aiken, South Carolina 29808

Phone/Fax: (800) 881-7292

e-mail: nepa@srs.gov

Background: When established in the early 1950s, SRS's primary mission was to produce special nuclear materials to support the defense, research, and medical programs of the United States. SRS's present mission emphasizes waste management, environmental restoration, and D\&D of facilities that are no longer needed for SRS's traditional defense mission.

At the present time, there are approximately 3600 B-25 boxes of legacy low-level job-control waste remaining in E-Area Vaults from past SRS operations which are candidates for volume reduction. In addition approximately 3000 boxes of new waste are generated each year from current operations. Pollution prevention and waste minimization efforts have been in effect at the site since 1990 as a comprehensive approach required by DOE Order 5400.1, "General Environmental Protection Program". Source reduction and recycling has reduced the number of B-25 containers generated each year and has altered the mix of box contents. For example, radioactively 
contaminated tools and equipment are now collected for decontamination and subsequent reuse.

In the Waste Management EIS (DOE/EIS-0217) (WMEIS), DOE evaluated a number of treatment alternatives for low-level job-control waste. The EIS states in Section 2.6.3 that expected treatment of LLW, known as Alternative $B$, will "...reduce the volume of low-activity job-control and equipment waste at commercial facilities; residuals would be returned to SRS for further treatment or disposal."

Recently, a review of LLW streams originally planned to be sent offsite for processing and then returned to SRS for disposition was performed. It was determined that it would be more advantageous to have the capability to process these waste streams onsite.

Proposed Action: The proposed action is to construct, operate, and D\&D a facility to process low-activity job-control and equipment waste for volume reduction. This waste consists of both legacy waste produced in the past and newly generated waste. The projected throughput is estimated at $4500 \mathrm{~B}-25$ boxes annually for single-shift operation. Three-shift operation of the facility is possible, in which case, up to 7000 boxes annually could be processed.

Sorting would produce six types of waste:

1. Waste that is combustible as-is - this waste would be placed in bags for packaging in 533-mm (21-in) square cardboard boxes.

2. Combustible waste that must be shredded to fit in 533-mm (21-in) square cardboard boxes - this waste would be taken to the shredder

3. Non-combustible waste that can be compacted - this waste would be packed into drums or hoppers for transport to either an in-box compactor or a drum supercompactor.

4. Scrap or salvageable material (e.g. tools) that can be decontaminated for reuse - this waste would be packed into containers awaiting decontamination.

5. Non-combustible, non-compactible, and other waste - this waste would be packed into containers for further evaluation and disposition.

6. Material that can be shown to be monitored for free-release - this material would be packed into containers for general, unrestricted release (reuse, recycle, sale).

Heavy waste such as valves and pumps would be left in the original container and sent to the decontamination facility. B-25 containers with waste for disposal, decontamination, or other disposition would go to exterior decontamination before release. Empty B-25 
boxes would also go to exterior decontamination before release. Shredded combustible waste would be placed in small plastic bags directly from the shredder auger. The bags would be surveyed and passed to a repackaging area for placement into 533-mm (21-in) square cardboard boxes. After waste packages have been surveyed and released from the facility, they can be transported to their next destination.

Alternatives: In accordance with NEPA regulations, DOE examined the following alternatives to the proposed action:

- Send Some LLW Offsite for Sorting, Shredding, and Compaction and Disposal of Balance (No Action) - continuation of the status quo:

The volume of compactible LLW would be reduced by on-site compactors and sent offsite for supercompaction, size reduction (e.g., sorting, shredding, melting), and incineration. Some LLW would be disposed of without treatment, treated offsite for recycling or later disposal at SRS, or burned in the Consolidated Incineration Facility (CIF). The resulting treatment residues would be disposed of in vaults or by shallow-land disposal. This is the part of moderate treatment configuration (Alternative B) analyzed in the WMEIS as the preferred alternative and selected for implementation in the Record of Decision (ROD) issued on September 22, 1995. It was also the subject of the Off-Site Volume Reduction of Low-Level Radioactive Waste EA (DOE/EA-1061) and its associated FONSI. While some waste may still be sent offsite for volume reduction, most would be retained onsite as it is difficult to assess, with a high degree of certainty, if a particular B-25 is acceptable for off-site shipment to a commercial facility.

- Send All LLW to E-Area Low-Level Waste Vault Unsorted:

This alternative is similar to the case for LLW evaluated as the no-action alternative in the WMEIS and the no-action alternative analyzed in the Off-Site Volume Reduction of Low-Level Radioactive Waste EA (DOE/EA-1061). The waste would be segregated into several categories for proper management. Some waste would be compacted to reduce its volume and it, along with the balance of noncompacted waste, would be disposed of in E-Area Vaults. This alternative was rejected as expensive vault space is wasted by filling it with waste that could otherwise be burned in CIF.

- Other Technologies:

DOE has reconsidered previously evaluated LLW treatment alternatives such as to construct pretreatment facilities for the waste and to construct and operate a non-alpha waste vitrification facility. These types of facilities were discussed in the WMEIS as part of an Extensive Treatment Configuration which also included a soil sort 
capability. DOE has found none of them to be acceptable for the same reasons described in the ROD issued for the WMEIS on September 22, 1995.

Environmental Impacts: Impacts were evaluated for both normal operation and for accident situations. Cumulative impacts were also evaluated.

- Normal Operation:

There would be no measurable impacts to the local economy as a result of the proposed action. The change in site usage of domestic and potable water would not be measurable. The change in volume of sanitary wastewater treated would not be measurable. There is expected to be no measurable impact on the site streams and wetlands as a result of this action. The WSF will not impact the amount of vehicle traffic associated with activities at the site.

The dose to the maximally exposed individual at the site boundary for an atmospheric radioactive release from the WSF was calculated using the EPA computer code, CAP88. Using a typical B-25, the total radiation dose to the maximally exposed individual is $1.29 \mathrm{E}-06 \mathrm{mrem}$. Stated another way, approximately $77,500 \mathrm{~B}-25 \mathrm{~s}$ per year could be processed by the WSF with a total dose to the maximally exposed individual of $0.1 \mathrm{mrem}$. Operation of the WSF would result in doses well within DOE limits. Thus the extremely low doses associated with the processing of 7000 B-25s per year (3-shift operation) would not contribute to off-site public exposure.

Some radiological exposure would be expected for the workers involved in the proposed packaging and loading. The worker dose for individuals working at the WSF was calculated using manifest data from 2,952 B-25s to generate an "average B-25". The dose rate associated with sorting the contents of an average B-25 ( 0.00022 rem per hour) is very low. Each shift of operation is anticipated to involve up to 10 workers for approximately 8 hours. Therefore, the proposed action would not significantly contribute to the annual worker exposure.

Because the proposed action involves processing wastes at SRS in lieu of shipping the waste offsite, the proposed action will involve less transportation than current activities. As all transportation would occur within E-Area, there are no risks to the public. As E-Area routinely handles and transports B-25s, no increased on-site transportation risk is expected to be associated with this action. On-site transportation risks associated with the WSF is bound by those addressed in the WMEIS.

- Accident:

As a maximum case 3-shift operation processing 7000 B-25s a year could involve processing approximately $12 \mathrm{~B}-25 \mathrm{~s}$ per shift. Changes in operations could result in significant variations in the total number of B-25s being processed and or staged for 
processing in the cell at any one time. In any event this would be significantly fewer B-25s than one of E-Area Vault cells would contain when it is filled with B-25s prior to final disposition. An E-Area Vault cell can hold up to 100 times the number of B-25s that will be processed at any one time in the WSF. Using the dose-to-risk conversion factors of $4.0 \mathrm{E}-4$ and $5.0 \mathrm{E}-4$ (onsite and offsite, respectively) Latent Cancer Fatalities (LCFs) per person-rem (56 FR 23363), a fire that would consume a cell completely full of B-25s would result in $0.01 \mathrm{LCFs}$ onsite and $0.04 \mathrm{LCFs}$ offsite. The actual inventory that would be present in the WSF would be approximatly 100 times less than the inventory analyzed here. Therefore, a release of the entire inventory in the WSF would result in no on-site or off-site LCFs.

- Cumulative Impacts:

The cumulative impacts of the disposition of the WSF process outputs are analyzed in and bounded by existing NEPA documents; Waste Management EIS (DOE/EIS-0217), Consolidated Inceneration Facility EA (DOE/EA-0400), Off-Site Volume Reduction of LLW EA (DOE/EA-1061), and Waste Management Activities for Groundwater Protection EIS (DOE/EIS-0120).

Determination: Based on the information and analyses in the attached EA (DOE/EA-1229), and after careful consideration of all comments, DOE has determined that the proposed construction, operation and D\&D of the WSF for the sorting, shredding, and compaction of radioactive LLW at SRS does not constitute a major Federal action significantly affecting the quality of the human environment with the meaning of NEPA. Therefore, an EIS is not required and DOE is issuing this FONSI.

Signed in Aiken, South Carolina, this _ 1998.

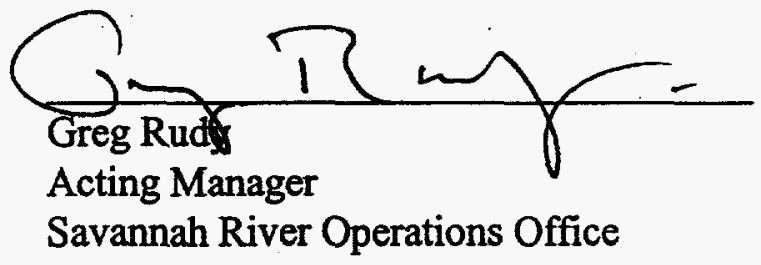




\title{
DOE/EA-1229
}

\section{ENVIRONMENTAL ASSESSMENT FOR THE \\ CONSTRUCTION, OPERATION, AND \\ DECOMMISSIONING OF THE \\ WASTE SEGREGATION FACILITY \\ AT THE \\ SAVANNAH RIVER SITE}

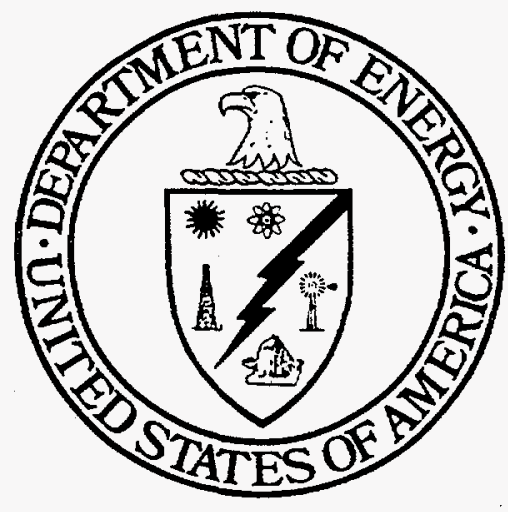

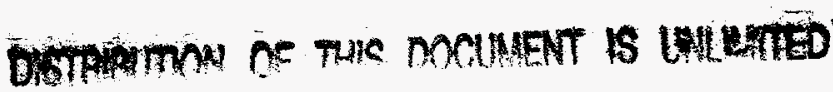

\author{
JANUARY 1998
}

U. S. DEPARTMENT OF ENERGY

SAVANNAH RIVER OPERATIONS OFFICE

SAVANNAH RIVER SITE 


\section{DISCLAIMER}

This report was prepared as an account of work sponsored by an agency of the United States Government. Neither the United States Government nor any agency thereof, nor any of their employees, makes any warranty, express or implied, or assumes any legal liability or responsibility for the accuracy, completeness, or usefulness of any information, apparatus, product, or process disclosed, or represents that its use would not infringe privately owned rights. Reference berein to any specific commercial product, process, or service by trade name, trademark, manufacturer, or otherwise does not necessarily constitute or imply its endorsement, recommendation, or favoring by the United States Government or any agency thereof. The views and opinions of authors expressed herein do not necessarily state or reflect those of the United States Government or any agency thereof. 


\section{DISCLAIMER}

Portions of this document may be illegible electronic image products. Images are produced from the best available original document. 


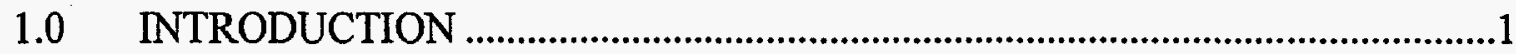

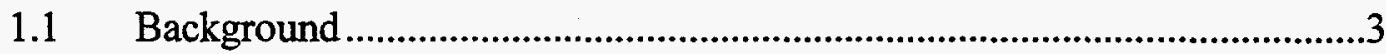

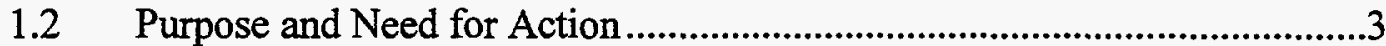

$2.0 \quad$ PROPOSED ACTION AND ALTERNATIVES …...........................................



2.1.1 Sort, Shred, and Compact LLW on Site (Preferred Alternative) .....4

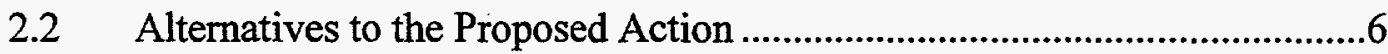

2.2.1 Send Some LLW Offsite for Sorting, Shredding, and Compaction and Disposal of Balance (No Action) ................................................

2.2.2 Send All LLW to E-Area LLW Vault Unsorted ...............................

2.2.3 Other Technologies.........................................................................

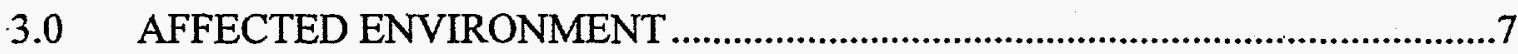

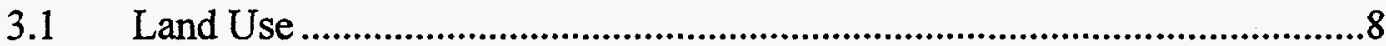

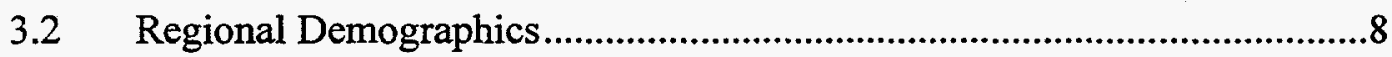

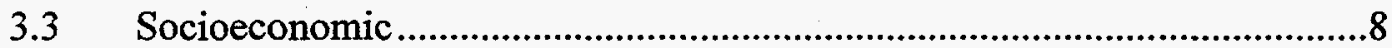

3.4 Meteorology and Climatology ................................................................

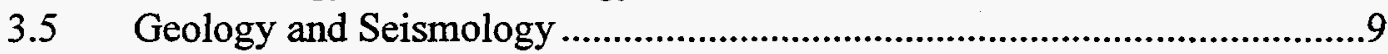

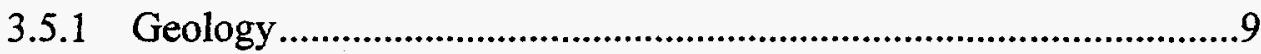

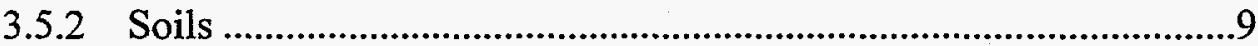

3.5.3 Seismology ................................................................................ 10

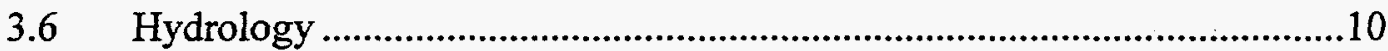

3.7 Ecological and Cultural Resources ..........................................................11

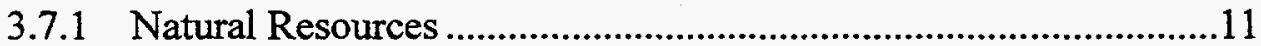

3.7.2 Historical Resources .............................................................11

3.7.3 Cultural Resources .........................................................................12

3.8 Radiation Environment .........................................................................12

4.0 ENVIRONMENTAL CONSEQUENCES OF THE PROPOSED ACTION AND

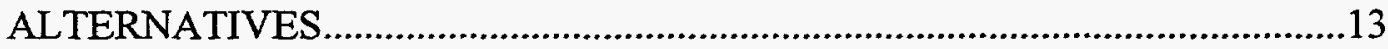

4.1 Human Health Effects..........................................................................13 
4.1.1 Maximally Exposed Individual..................................................13

4.1.2 Worker Dose ............................................................................14

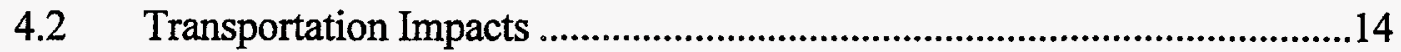

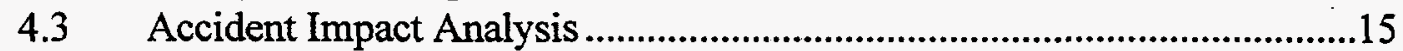

4.4 Decontamination and Decommissioning .................................................15

4.5 Environmental Consequences of the Alternatives ......................................15

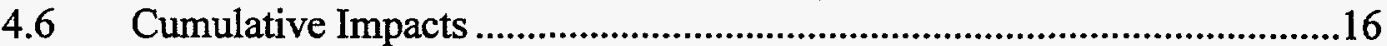

5.0 REGULATORY AND PERMITTING PROVISION CONSIDERATIONS.........16

5.1 National Environmental Policy Act of 1969, as Amended (42 USC 4321 et seq.).....................................................................................................16

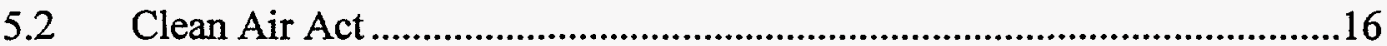

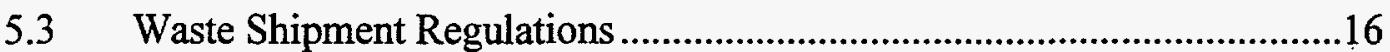

5.4 Additional Regulatory, Permitting Provisions, and Site Requirements.....17

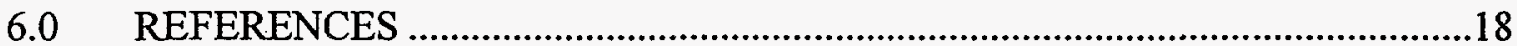

\section{APPENDIXES:}

APPENDIX A: $\quad$ Facility Descriptions

APPENDIX B: $\quad$ Treatment............................................................................

\section{LIST OF FIGURES}

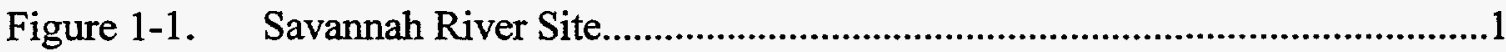

Figure 2-1 Conceptual Facility Configuration...............................................................

Figure 2-2 $\quad$ E-Area.............................................................................................

Figure B-1 Treatment Process Flow...................................................................... B-1

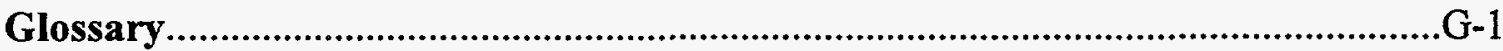

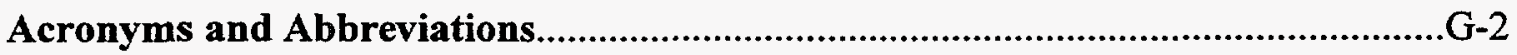




\subsection{INTRODUCTION}

This Environmental Assessment (EA) has been prepared by the Department of Energy (DOE) to assess the potential environmental impacts associated with the construction, operation and decontamination and decommissioning (D\&D) of the Waste Segregation Facility (WSF) for the sorting, shredding, and compaction of low-level radioactive waste

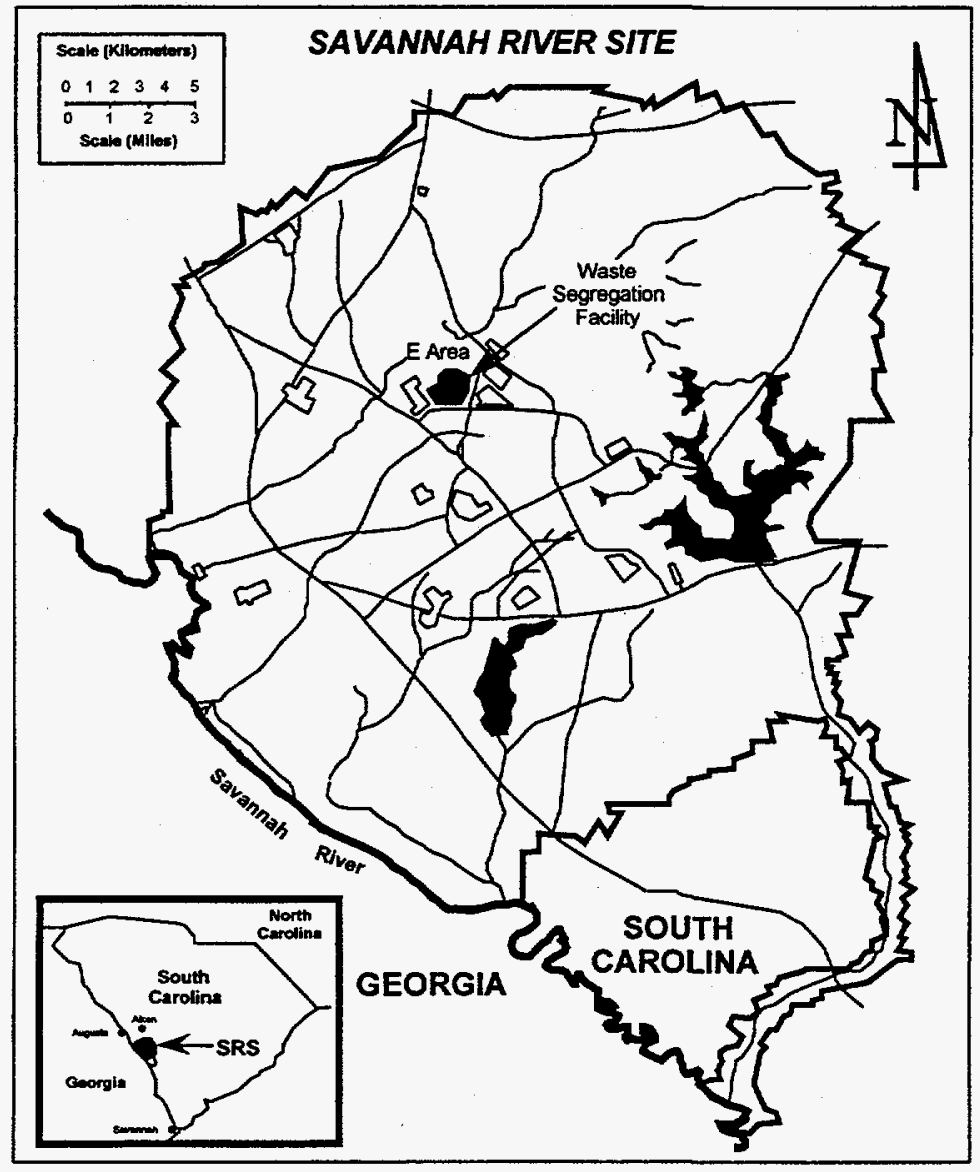

Figure 1-1 Savannah River Site
(LLW) at the Savannah River Site (SRS) located near Aiken, South Carolina (Figure 1-1). The LLW to be processed consists of two waste streams: legacy waste which is currently stored in E-Area Vaults of SRS and new waste generated from continuing operations.

The proposed action is to construct, operate, and D\&D a facility to process low-activity job-control and equipment waste for volume reduction. The LLW would be processed to make more efficient use of low-level waste disposal capacity (E-Area Vaults) or to meet the waste acceptance criteria for treatment at the Consolidated Incineration Facility (CIF) at SRS.

The waste management activities at SRS have been the subject of several NEPA reviews. The environmental impacts of operation of E-Area Vaults were evaluated in the Waste Management Activities for Groundwater Protection Environmental Impact Statement (EIS) (DOE, 1987) and the Waste Management Environmental Impact Statement (WMEIS) (DOE, 1995a). The environmental impacts of operation of the CIF were evaluated in the CIF Environmental Assessment (DOE, 1992) and the WMEIS. The processing of LLW offsite was evaluated in the EA for the Off-Site Volume Reduction of LLW (DOE, 1995b) and the WMEIS (DOE, 1995a). 
During the development of the WMEIS the draft EIS discussed:

- Continue to compact with SRS low force compactor (Page 2-170 Section2.6.3/Page 4-192 Section 4.4)

- Construct and operate a supercompactor (Page 2-170 Section2.6.3/Page 4-192 Section 4.4)

- CIF accepts LLW that would be packaged/stored/handled in 533-mm (21-in) boxes (Page 2-170 Section2.6.3/Page 4-192 Section 4.4)

- Vitrification pretreatment (shredding) (Page 2-139 Section2.5.3/Page 4-133 Section 4.3)

In the final EIS the following were discussed:

- CIF accepts LLW that would be packaged/stored/handled in 533-mm (21-in) boxes (Page 2-176 Section2.6.3/Page 4-191 Section 4.4)

- Volume reduction would take place offsite using a commercial facility (Page 2-176 Section2.6.3/Page 4-191 Section 4.4)

- Vitrification pretreatment (shredding) (Page 2-1145 Section2.5.3/Page 4-131 Section 4.3)

As a result of this action there would be no change in the waste matrix discussed in the WMEIS. Currently the LLW meets E-Area Vault Waste Acceptance Criteria (WAC), and after processing through the WSF, it would meet E-Area Vault WAC or the CIF WAC, as applicable. The CIF WAC (WSRC, 1993) requires that combustible waste be packaged in 533-mm (21-in) boxes.

As the WSF was not explicitly analyzed in the WMEIS (DOE, 1995a), this EA is being prepared to further the purposes of NEPA as provided in 10 CFR 1021.321(a) which states that "DOE may prepare an EA on any action at any time in order to assist agency planning and desision making." In accordance with 10 CFR 1021.210(e) and as provided in 40 CFR 1502.20 and .21, DOE has also descided to tier this EA to the WMEIS in order to concentrate on issues specific to the proposed action.

This document was prepared in compliance with the National Environmental Policy Act of 1969, as amended, the Council on Environmental Quality Regulations for Implementing NEPA (40 CFR 1500-1508), and the DOE Regulation for implementing NEPA (10 CFR 1021). NEPA requires the assessment of environmental consequences of Federal actions that may affect the quality of the human environment. Based on the potential for impacts described herein, DOE would either publish a Finding of No Significant Impact (FONSI) or prepare an EIS. 


\section{$1.1 \quad$ Background}

When established in the early 1950 s, SRS's primary mission was to produce special nuclear materials to support the defense, research, and medical programs of the United States. SRS's present mission emphasizes waste management, environmental restoration, and D\&D of facilities that are no longer needed for SRS's traditional defense mission.

At the present time, there are approximately 3600 B-25 boxes of legacy low-level job-control waste remaining in E-Area Vaults from past SRS operations which are candidates for volume reduction. In addition approximately 3000 boxes of new waste are generated each year from current operations. Pollution prevention and waste minimization efforts have been in effect at the site since 1990 as a comprehensive approach required by DOE Order 5400.1, "General Environmental Protection Program". Source reduction and recycling has reduced the number of B-25 containers generated each year and has altered the mix of box contents. For example, radioactively contaminated tools and equipment are now collected for decontamination and subsequent reuse.

In the WMEIS (DOE, 1995a), DOE evaluated a number of treatment alternatives for low-level job-control waste. The EIS states in Section 2.6.3 that expected treatment of LLW, known as Alternative B, would "...reduce the volume of low-activity job-control and equipment waste at commercial facilities; residuals would be returned to SRS for further treatment or disposal." This alternative, implemented in 1996, consists of:

- sorting and compaction at an off-site facility to reduce gross volume

- return of repackaged combustible waste to SRS for incineration

- disposal of non-combustible waste onsite.

Recently, a review of LLW streams originally planned to be sent offsite for processing and then returned to SRS for disposition was performed. It was determined that it would be more advantageous to have the capability to process these waste streams onsite (WSRC, 1996b). The main issue is that the consistancy of the radionuclide composition varies between waste streams and from B-25 to B-25. This makes it difficult to assess with a high degree of certainty if a particular B-25 is acceptable for off-site shipment to a commercial facility where it would be opened and processed.

\section{1:2 Purpose and Need for Action}

DOE needs to make efficient use of waste disposal facilities to minimize the need for costly vault disposal facilities. DOE needs to separate LLW into combustible and compactible streams in order to take advantage of the capability of CIF and to reduce the need for new disposal vault space. The LLW would be processed to make more efficient 
use of LLW disposal capacity or to meet the waste acceptance criteria for treatment at the CIF at SRS.

\subsection{PROPOSED ACTION AND ALTERNATIVES}

\subsection{Proposed Action}

The proposed action is to construct, operate, and D\&D a facility to process low-activity job-control and equipment waste for volume reduction. This waste consists of both legacy waste produced in the past and newly generated waste. The projected throughput is estimated at 4500 B-25 boxes annually for single-shift operation. Three-shift operation of the facility is possible, in which case, up to 7000 boxes annually could be processed. The process streams are detailed in Appendix B, Treatment Process Flow.

\subsubsection{Sort, Shred, and Compact LLW On-site (Preferred Alternative)}

The proposed action is to construct, operate, and D\&D a facility to process low-activity job-control and equipment waste for volume reduction. It would include various volume reduction and sorting steps including sorting, shredding, boxed waste compaction and drummed waste compaction.

Candidate B-25 boxes would be selected from E-Area Vaults and staged in the sorting room. Workers would place the boxes in the box opening confinement area, where the lid would be removed. A box tipper would raise the waste so that workers outside the confinement area can move bags of waste into the sorting glove box. Sorting would produce six types of waste:

1. Waste that is combustible as-is - this waste would be placed in bags for packaging in $533-\mathrm{mm}$ (21-in) square cardboard boxes.

2. Combustible waste that must be shredded to fit in $533-\mathrm{mm}$ (21-in) square cardboard boxes - this waste would be taken to the shredder

3. Non-combustible waste that can be compacted - this waste would be packed into drums or hoppers for transport to either an in-box compactor or a drum supercompactor.

4. Scrap or salvageable material (e.g. tools) that can be decontaminated for reuse - this waste would be packed into containers awaiting decontamination.

5. Non-combustible, non-compactible, and other waste - this waste would be packed into containers for further evaluation and disposition. 
6. Material that can be shown to be monitored for free-release - this material would be packed into containers for general, unrestricted release (reuse, recycle, sale).

Heavy waste such as valves and pumps would be left in the original container and sent to the decontamination facility. B-25 containers with waste for disposal, decontamination, or other disposition would go to exterior decontamination before release. Empty B-25 boxes would also go to exterior decontamination before release. Shredded combustible waste would be placed in small plastic bags directly from the shredder auger. The bags would be surveyed and passed to a repackaging area for placement into 533-mm (21-in) square cardboard boxes. After waste packages have been surveyed and released from the facility, they can be transported to their next destination (WSRC, 1997b).

A broad range of facility configurations and locations within E-Area have been evaluated

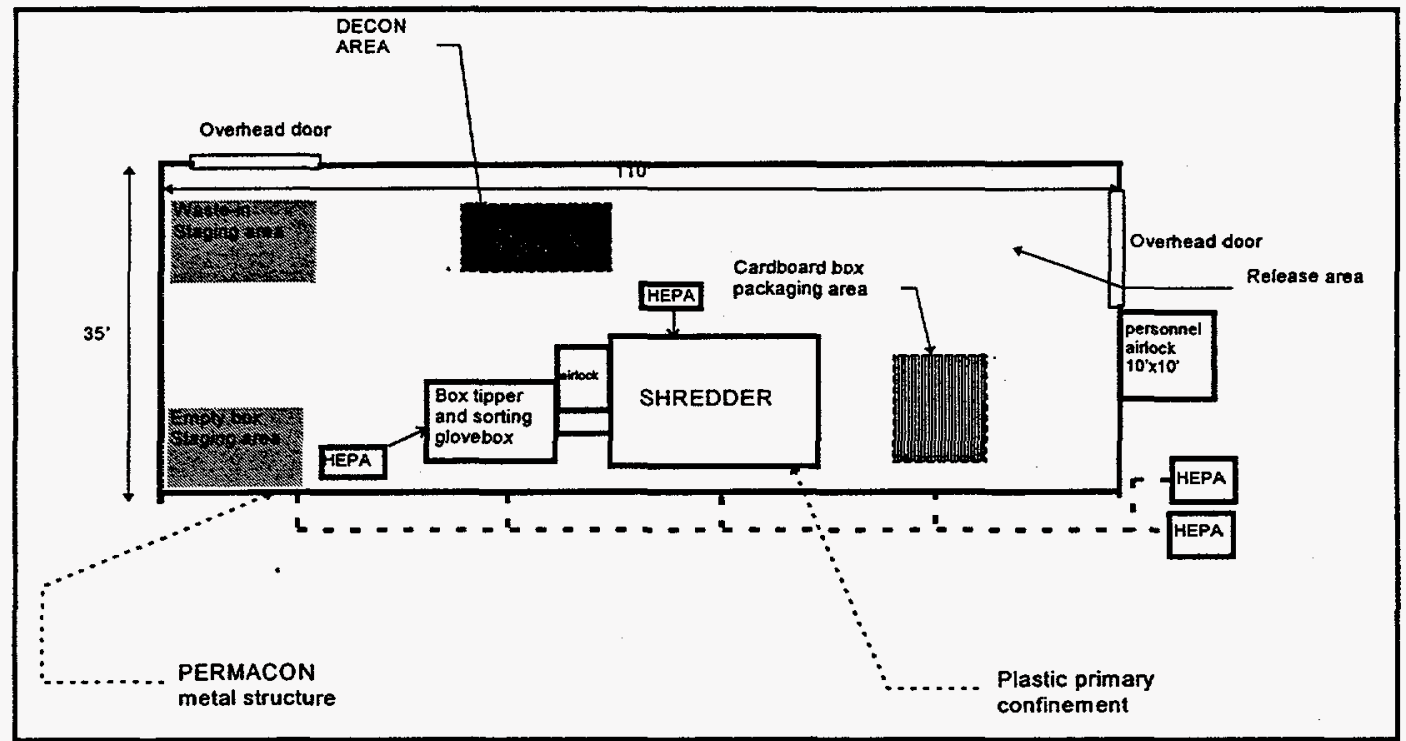

Figure 2-1 Conceptual Facility Configuration

(WSRC, 1997b). Locations considered included existing concrete pads (e.g. Pad 6), new concrete slabs, and placement within an existing E-Area Vault (e.g. Vault 12). Regardless of construction or location all share common elements of concrete floor, containment structure, HEPA filters, airlocks, etc. See Figure 2-1 for a conceptual facility configuration and Figure 2-2 for a layout of E-Area.

The projected throughput is estimated at $4500 \mathrm{~B}-25$ boxes annually. Surge capacity to 3 shifts is possible which would allow the processing of approximately 7000 boxes annually. The activity would be located within a vault in E-Area with a supercompactor located adjacent to the vault. 


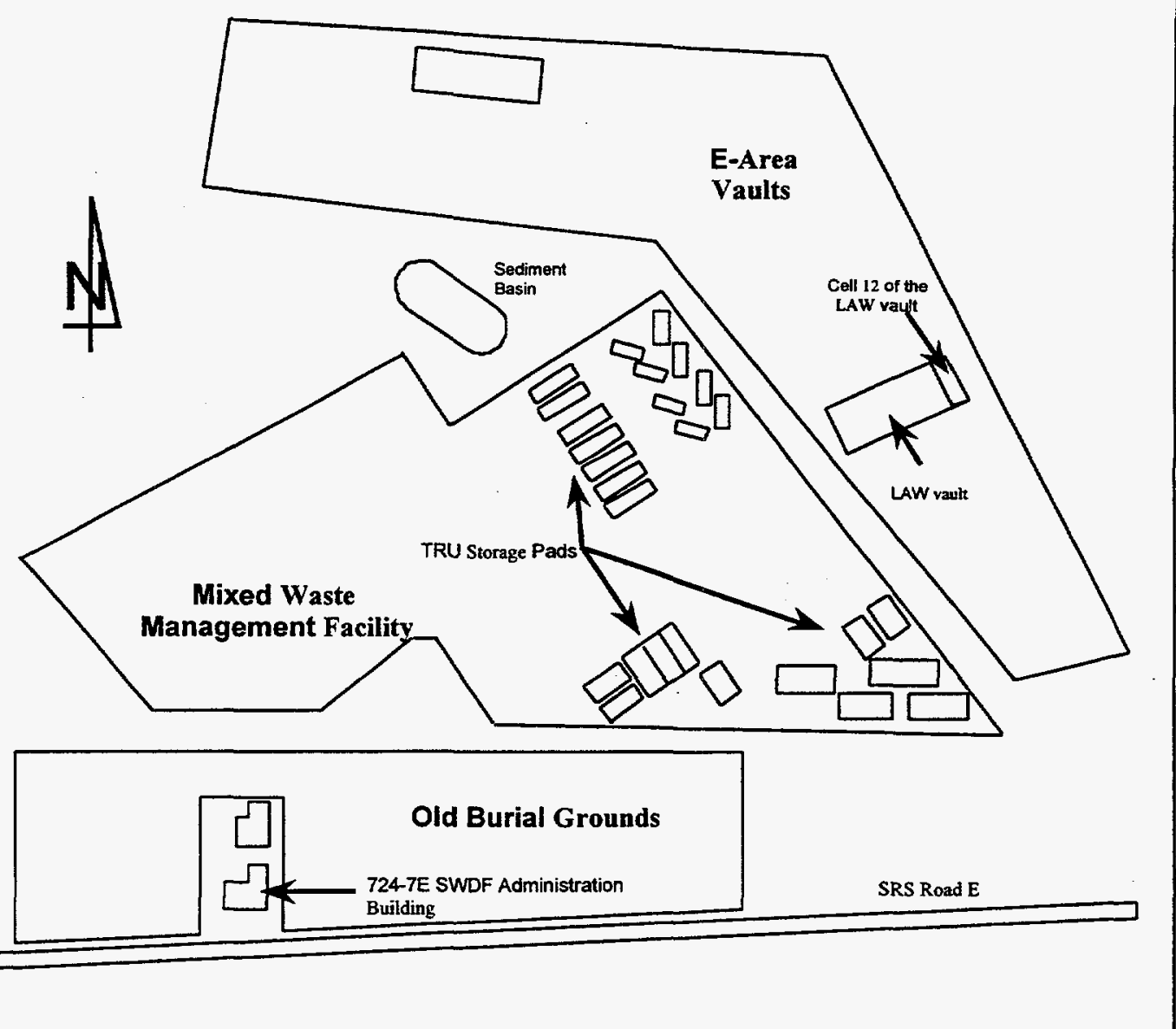

Figure 2-1 E-Area

\subsection{Alternatives to the Proposed Action}

In accordance with NEPA regulations, DOE examined the following alternatives to the proposed action:

- Send some LLW offsite for sorting, shredding, and compaction and disposal of balance (No Action) - continuation of the status quo.

- Send all LLW to E-Area LLW Vault unsorted

- Other technologies

2.2.1 Send Some LLW Offsite for Sorting, Shredding, and Compaction and Disposal of Balance (No Action)

The volume of compactible LLW would be reduced by on-site compactors and sent offsite for supercompaction, size reduction (e.g., sorting, shredding, melting), and incineration. Some LLW would be disposed of without treatment, treated offsite for 
recycling or later disposal at SRS, or burned in the CIF. The resulting treatment residues would be disposed of in vaults or by shallow-land disposal. This is the part of moderate treatment configuration (Alternative B) analyzed in the WMEIS (DOE, 1995a) as the preferred alternative and selected for implementation in the Record of Decision (ROD) issued on September 22, 1995. It was also the subject of the Off-Site Volume Reduction of Low-Level Radioactive Waste EA (DOE, 1995b) and its associated FONSI.

\subsubsection{Send All LLW to E-Area LLW Vault Unsorted}

This alternative is similar to the case for LLW evaluated as the no-action alternative in the WMEIS (DOE, 1995a) and the no-action alternative analyzed in the EA for the Off-Site Volume Reduction of Low-Level Radioactive Waste (DOE, 1995b). The waste would be segregated into several categories for proper management. Some waste would be compacted to reduce its volume and it, along with the balance of noncompacted waste, would be disposed of in E-Area Vaults.

\subsubsection{Other Technologies}

DOE has reconsidered previously evaluated LLW treatment alternatives such as to construct pretreatment facilities for the waste and to construct and operate a non-alpha waste vitrification facility. These types of facilities were discussed in the WMEIS as part of an Extensive Treatment Configuration which also included a soil sort capability. Details on such a facility can be found in the WMEIS in Section 2.5.3.1 (DOE, 1995a). DOE has found none of them to be acceptable (WSRC, 1997b) for the same reasons described in the ROD issued for the WMEIS on September 22, 1995.

\subsection{AFFECTED ENVIRONMENT}

SRS is located in southwestern South Carolina adjacent to the Savannah River, which forms the boundary between South Carolina and Georgia. It encompasses approximately 800 square kilometers (300 square miles) within the Atlantic Coastal Plain physiographic province. SRS is approximately 40-kilometers (25-mi) southeast of Augusta, Georgia, and 32-km (20-mi) south of Aiken, South Carolina. Figure 1-1 shows the location of SRS within the South Carolina-Georgia region.

SRS is a controlled area with limited public access. Through traffic is allowed only on SC Highway 125, U.S. Highway 278, SRS Road 1, and CSX railroad corridors. SRS areas and facilities include: five nuclear production reactor areas (C-, K-, L-, P-, and R-Reactors); a nuclear target and fuel fabrication facility (M-Area), which assembled the targets and fuel that went into the reactors; two chemical separations areas (F- and H-Areas), which processed irradiated targets and fuel assemblies to separate and recover various isotopes and which contain the liquid high-level radioactive waste tank farms; a waste vitrification facility (S-Area), which vitrifies liquid high-level radioactive waste; a saltstone facility (Z-Area), which solidifies low-level radioactive sludge into a cement-like matrix; N-Area, where some wastes are stored; E-Area, which includes waste 
treatment, storage, and disposal facilities; and various administrative, support, and research facilities. These facilities have generated a variety of liquid high-level radioactive, low-level radioactive, hazardous, mixed (hazardous and radioactive), and transuranic wastes.

\subsection{Land Use}

E-Area is highly industrialized and has been so since 1952 when the Old Burial Grounds (643-G) began receiving waste (Jaegge et al., 1987). E-Area is situated in the northcentral portion of SRS, bounded by Upper Three Runs to the north and Fourmile Branch to the south. Land within an 8-kilometer (5-mile) radius of these areas lies entirely within the SRS boundaries and is used for either industrial purposes or as forested land (DOE, 1994a).

\subsection{Regional Demographics}

Within an $80-\mathrm{km}(50-\mathrm{mi})$ radius of the center of SRS is a total resident population of approximately 730,000 . One major urban center, Augusta, Georgia (1990 population of 44,639 ) (renamed August-Richmond County in 1995 with a population greater than $150,000)$, lies about $40-\mathrm{km}(25-\mathrm{mi})$ west-northwest of the site. Four other cities within the $80-\mathrm{km}(50-\mathrm{mi})$ radius had 1990 populations greater than 13,000: Aiken, South Carolina, about 32-km (20-mi) north-northwest; Orangeburg, South Carolina, 77-km (48-mi) east-northeast; North Augusta, South Carolina, 37-km (23-mi) northwest; and Evans, Georgia, about 56-km (35-mi) west-northwest of the site. All other cities and towns have populations less than 7,000, the largest being Belvedere, South Carolina, followed by Red Bank, South Carolina, Waynesboro, Georgia, and Barnwell, South Carolina (WSRC, 1995).

The industrial population, consisting primarily of the SRS work force, Vogtle Electric Generating Plant employees, and employees of 16 smaller industries located in or near Barnwell, Williston, New Ellenton, and Jackson, South Carolina, comprise a daily transient population of approximately 25,734. Most of this total population works Monday through Friday from about 8:00 a.m. to 4:00 p.m. These workers spend an average of about 45 hours per week at the worksite. The industrial population within a 8-kilometer (5-mile) radius of $\mathrm{F}$ - and H-Areas consists entirely of about 14,000 SRS employees at A/M-, B-, C-, N-, E-, F-, H-, K-, R-. S-, and Z-Areas (WSRC, 1995).

\subsection{Socioeconomic}

The WSF would be constructed by either on-site labor or by a subcontractor. Construction workers are expected to be in E-Area for approximately a month. Approximately five construction workers would be at the facility for several weeks to assemble and install the equipment, confinement structures, and ventilation systems. In addition, two to three technicians would be at the WSF for 2 weeks to complete wiring 
and electrical testing prior to startup. Construction activities would have minimal impact on the surrounding area due to the small number of construction workers involved.

The workforce to be employed at the WSF would consist of approximately 8 to 10 individuals for a single-shift operation. The WSF could operate on a 3-shift basis and employ approximately 24 individuals. It is expected that all of this workforce would be composed of current SRS employees rather than new workers immigrating into the SRS area.

The WMEIS (DOE, 1995a) and the most recent socioeconomic survey of the six-county SRS area of influence (NUS, 1997) contains additional information on the areas surrounding SRS.

\subsection{Meteorology and Climatology}

The SRS region has a temperate climate with mild winters and long summers. The average annual rainfall at SRS is about $122 \mathrm{~cm}$ (48 in) and the average wind speed in 1987-91 was $13.7 \mathrm{~km} / \mathrm{hr}$ (8.5 mi/hr) (WSRC, 1989; DOE, 1995a). Tornadoes have been observed during every month of the year in the area encompassing SRS, but occur most frequently in the spring (WSRC, 1989). Only a few instances of slight to moderate tornado damage to support facilities have been documented for the site to date. The WMEIS (DOE, 1995a) contains additional information on SRS meteorology and climatology. The general meteorological and climatological data for SRS would be representative of that for E-Area.

\subsection{Geology and Seismology}

\subsubsection{Geology}

SRS is located on the Aiken Plateau of the Upper Atlantic Coastal Plain physiographic province about 40-kilometers (25-miles) southeast of the Fall Line that separates the Atlantic Coastal Plain from the Piedmont physiographic province (Figure 3-3). The Aiken Plateau is highly dissected and consists of broad, flat areas between streams and narrow, steep-sided valleys. It slopes from an elevation of approximately $200 \mathrm{~m}(650 \mathrm{ft})$ at the Fall Line to an elevation of about $75 \mathrm{~m}(250 \mathrm{ft})$ on the southeast edge of the plateau. Because of SRS's proximity to the Piedmont province, it is somewhat more hilly than the near-coastal areas, with on-site elevations ranging from 27 to $128 \mathrm{~m}$ (90 to 420 $\mathrm{ft}$ ) above sea level. Relief on the Aiken Plateau is as much as $90 \mathrm{~m}$ (300 ft) locally. The plateau is generally well drained, although small poorly drained depressions do occur.

\subsubsection{Soils}

Previously disturbed soils are mostly well drained and were taken from excavated areas, borrow pits, and other areas where major land-shaping or grading activities have occurred such as sidewalks, buildings, parking lots, and other structures. Much of the soil in the 
existing waste management areas has been moved, so soil properties can vary within a few meters. Slopes of soils generally range from 0 to 10 percent and have a moderate erosion hazard. These disturbed soils range from a consistency of sand to clay, depending on the source of the soil material (USDA, 1990).

Undisturbed soils at SRS generally consist of sandy surface layers above a subsoil containing a mixture of sand, silt, and clay. These soils are gently sloping to moderately steep (0 to 10 percent grade) and have a slight erosion hazard (USDA, 1990). Some soils on uplands are nearly level, and those on bottomlands along the major streams are level. Soils in small, narrow drainage valleys are steep. Most of the upland soils are well drained to excessively drained. The well-drained soils have a thick, sandy surface layer that extends to a depth of 2 meters $(7 \mathrm{feet})$ or more in some areas. The soils on bottomlands range from well drained to very poorly drained. Some soils on the abrupt slope breaks have a dense, brittle subsoil.

\subsubsection{Seismology}

Several fault systems occur offsite, northwest of the Fall Line. DOE (1990) contains a detailed discussion of these off-site geologic features. A recent study (Stephenson and Stieve, 1992) identified six faults under SRS: Pen Branch, Steel Creek, Advanced Tactical Training Area (ATTA), Crackerneck, Ellenton, and Upper Three Runs Faults. Identification of faults is important because earthquakes can occur along these faults. The location of faults must be considered when siting hazardous waste management facilities. South Carolina Department of Health and Environmental Control (SCDHEC) regulations specify a setback distance of at least $61 \mathrm{~m}(200 \mathrm{ft})$ from a fault where displacement during the Holocene Epoch (approximately 35,000 years ago to the present)

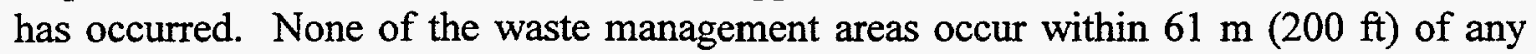
faults, nor is there evidence that any of the identified faults have moved in the last 35,000 years.

Based on information developed to date, none of the faults discussed in this section are considered "capable," as defined by the Nuclear Regulatory Commission (NRC) in 10 CFR 100, Appendix A. The capability of a fault is determined by several criteria, one of which is whether the fault has moved at or near the ground surface within the past 35,000 years.

\subsection{Hydrology}

The Savannah River forms the western boundary of SRS and receives drainage from five major tributaries on the site: Upper Three Runs, Fourmile Branch, Pen Branch, Steel Creek, and Lower Three Runs. These tributaries receive varying types of wastewater discharges from plant processes and sanitary treatment systems, all of which are permitted through the National Pollutant Discharge Elimination System (NPDES). On SRS, various plant processes also require the pumping of Savannah River water and/or on-site groundwater. A recent EIS (DOE, 1995a) contains information on groundwater 
systems on SRS and in the surrounding region. In addition the area of interest, E-Area Vaults, was discussed in the Waste Management Activities for Groundwater Protection EIS (DOE, 1987).

\subsection{Ecological and Cultural Resources}

\subsubsection{Natural Resources}

Since 1951, when the U.S. Government acquired SRS, natural resource management practices and natural succession outside of the construction and operation areas at SRS have resulted in increased ecological complexity and diversity of the site. Forested areas support a diversity of wildlife habitats that are restricted from public use. Forest management practices include controlled burning, harvesting of mature trees, and reforesting. Wildlife management includes control of SRS white-tailed deer (Odocoileous virginianus) and wild swine (Sus scrofa) populations through supervised hunts. SRS, which was designated as the first National Environmental Research Park in 1972 , is one of the most extensively-studied environments in this country. The SRS Ecology: Environmental Information Document (Wike et al., 1994) contains additional information on the biotic characteristics of SRS.

Six species on SRS are afforded protection by the Federal government under the Endangered Species Act of 1973. They are the bald eagle (Haliaeetus leucocephalus), wood stork (Mycteria americana), red-cockaded woodpecker (Picoides borealis), American alligator (Alligator mississippiensis), shortnose sturgeon (Acipenser brevirostrum), and smooth purple coneflower (Echinacea laevigata).

Due to the industrial nature of E-Area, the plants or animals mentioned above do not exist within the boundaries of the fenced portion where the proposed activities would take place. A study has been performed on the Site's urban wildlife (WSRC, 1997b) which further documents wildlife found in industrialized areas of SRS.

\subsubsection{Historical Resources}

Field studies conducted over the past two decades by the South Carolina Institute of Archaeology and Anthropology of the University of South Carolina, under contract to DOE and in consultation with the South Carolina State Historic Preservation Officer, have provided considerable information about the distribution and content of archaeological and historic sites on SRS. By the end of September 1992, approximately 60 percent of SRS had been examined, and 858 archaeological (historic and prehistoric) sites had been identified. Of these, 53 have been determined to be eligible for the National Register of Historic Places; 650 have not been evaluated. No SRS facilities have been nominated for the National Register of Historic Places, and there are no plans for nominations at this time. The existing SRS nuclear production facilities are not likely to be eligible for the National Register of Historic Places, either because they lack architectural integrity, do not represent a particular style, or do not contribute to the broad 
historic theme of the Manhattan Project and the production of initial nuclear materials (Brooks, 1993, 1994).

\subsubsection{Cultural Resources}

In conjunction with studies in 1991 related to the New Production Reactor, DOE solicited the concerns of Native Americans about religious rights in the Central Savannah River Valley. During this study, three Native American groups, the Yuchi Tribal Organization, the National Council of Muskogee Creek, and the Indian People's Muskogee Tribal Town Confederacy, expressed general concerns about SRS and the Central Savannah River Area, but did not identify specific sites as possessing religious significance. The Yuchi Tribal Organization and the National Council of Muskogee Creek are interested in several plant species traditionally used in tribal ceremonies, such as redroot (Lachnanthes carolinianum), button snakeroot (Eryngium yuccifolium), and American ginseng (Panax quinquefolium) that may occur on SRS (NUS, 1991). Redroot and button snakeroot are known to occur on SRS (Batson, Angerman, and Jones, 1985). DOE includes all three tribal organizations on its mailing lists and sends them documents about SRS environmental activities.

\subsection{Radiation Environment}

Ambient air concentrations of radionuclides at SRS include nuclides of natural origins, such as radon from uranium in soils; man-made radionuclides, such as fallout from testing of nuclear weapons; and emissions from coal-fired and nuclear power plants. SRS operates a 35-station atmospheric surveillance program. Stations are located inside the SRS perimeter, on the SRS perimeter, and at distances up to 161 kilometers (100 miles) from SRS.

Routine SRS operations release quantities of alpha- and beta-gamma-emitting radioactive materials in the form of gases and particulates. Gross alpha and nonvolatile beta measurements are used as a screening method for determining the concentration of all radionuclides in the air. A person residing in the Central Savannah River Area (within 80 $\mathrm{km}(50 \mathrm{mi})$ of SRS) receives an average annual radiation dose of about $360 \mathrm{mrem}$. Natural radiation sources contribute about $295 \mathrm{mrem}$, medical exposures contribute about $53 \mathrm{mrem}$, and consumer products contribute about $10 \mathrm{mrem}$. SRS contributes $0.23 \mathrm{mrem}$ (less than 0.1 percent of that total).

The Savannah River Site Environmental Report for 1996 (WSRC, 1997e) contains more detailed information on the radiation environment at SRS. 


\subsection{ENVIRONMENTAL CONSEQUENCES OF THE PROPOSED ACTION AND ALTERNATIVES}

Most of the activities which are proposed to be conducted in the WSF were previously analyzed in the WMEIS (DOE, 1995a).

- The No-Action case and Alternative A of the WMEIS both addressed the ongoing onsite compaction of low-activity job-control waste. The on-site compactor is described in Appendix B.4 of the WMEIS. The volume considered was approximately $1500 \mathrm{~B}-25$ boxes annually.

- Alternative B in the WMEIS described sorting, repackaging, and size reduction of LLW. However these activities were to take place offsite. (The draft WMEIS did address the on-site supercompaction of low-level job-control waste.) The on-site supercompactor description and its operational impacts remained in Appendix B.29 in the WMEIS. In the maximum waste generation forecast, over $4700 \mathrm{~B}-25$ boxes were to be processed through the supercompactor annually.

- Alternative $\mathrm{C}$ in the WMEIS addressed the "pretreatment" of low-activity job-control waste, including shredding, as part of a larger vitrification facility. This vitrification facility was described in Appendix B.18 of the WMEIS.

\subsection{Human Health Effects}

\subsubsection{Maximally Exposed Individual}

As reported in the Savannah River Site Environmental Report for 1996 (WSRC 1997e), the potential dose to the hypothetical off-site maximally exposed individual during 1996 from Savannah River Site operations was $0.00019 \mathrm{rem}$. The potential dose to the local population of 620,100 persons from 1996 operations was 2.8 person-rem. The 1996 average dose to the population was 0.000005 rem per person. The current DOE radiation limit for an individual member of the public is 0.1 rem per year, and the national average dose from natural sources is 0.3 rem per year.

The dose to the maximally exposed individual at the site boundary for an atmospheric radioactive release from the WSF was calculated using the EPA computer code, CAP88. The use of CAP88 is required for demonstrating NESHAP (40 CFR 61) compliance. In accordance with 40 CFR 61 , the maximally exposed individual is assumed to be located at the nearest home, farm, business, or school and is assumed to eat vegetables, meat, and milk produced at that location. The maximally exposed individual at the site boundary is located at a distance of approximately 11,050 meters $(36,253 \mathrm{feet})$ to the north of the site. The release was assumed to be at ground level and to have occurred over 1 year. Using a typical B-25, the total radiation dose to the maximally exposed individual is $1.29 \mathrm{E}-06$ 
mrem (WSRC, 1997c). Stated another way, approximately 77,500 B-25s per year could be processed by the WSF with a total dose to the maximally exposed individual of 0.1 mrem. Operation of the WSF would result in doses well within DOE limits. Thus the extremely low doses associated with the processing of 7000 B-25s per year (3-shift operation) would not contribute to off-site public exposure.

\subsubsection{Worker Dose}

The potential for release of radioactivity from low-activity job-control and equipment waste during processing for volume reduction exists. However, appropriate controls would be in place in order to maintain radioactive personnel exposure well below DOE guidelines (5.0 rem per year), in keeping with As Low As Reasonably Achievable (ALARA) principles. Additionally, appropriate procedures and administrative controls (e.g., personnel training and a Radiation Work Permit) would be in place prior to any proposed activities. Radiation and hazardous chemical worker exposure levels would be monitored during the proposed actions (i.e., personal dosimeters and constant air monitors).

Some radiological exposure would be expected for the workers involved in the proposed packaging and loading. The worker dose for individuals working at the WSF was calculated using manifest data from 2,952 B-25s (WSRC, 1997d) to generate an "average B-25". The dose rate associated with sorting the contents of an average B-25 $(0.00022$ rem per hour) is very low. Each shift of operation is anticipated to involve up to 10 workers for approximately 8 hours. Therefore, the proposed action would not significantly contribute to the annual worker exposure.

The projected average occupational external whole-body exposure to personnel in E-Area due to routine operations in 1996 was approximately $0.0089 \mathrm{rem}$. This is substantially less than the maximum allowable exposure of 5.0 rem per year. Therefore, operations, based on a dose-to-risk conversion factors of 4.0E-4 (onsite) latent cancer fatalities (LCFs) per person-rem (roentgen equivalent man) (56 FR 23363), no LCFs per year would be expected to result from the WSF. It is anticipated that routine operations would not provide additional exposure of toxic or noxious vapors to workers.

\subsection{Transportation Impacts}

SRS is served by more than $320 \mathrm{~km}(199 \mathrm{mi})$ of primary roads and more than $1600 \mathrm{~km}$ ( $995 \mathrm{mi}$ ) of unpaved secondary roads. The primary highways used by SRS commuters are State Routes 19,64, and 125; 40,10, and 50 percent of the workers use these routes respectively. Significant congestion can occur during peak traffic periods onsite on SRS Road 1-A, State Routes 19 and 125, and U.S. Route 278 at SRS access points.

Because the proposed action involves processing wastes at SRS in lieu of shipping the waste offsite, the proposed action would involve less transportation than current activities. As all transportation would occur within E-Area, there are no risks to the 
public. As E-Area routinely handles and transports B-25s, no increased on-site transportation risk is expected to be associated with this action. On-site transportation risks associated with the WSF is bound by those addressed in the WMEIS (DOE 1995a).

\subsection{Accident Impact Analysis}

The proposed action involves sorting, shredding, and compacting low-level waste onsite. The preferred alternative would perform these activities in one cell of an E-Area Vault. As a maximum case 3-shift operation processing 7000 B-25s a year could involve processing approximately $12 \mathrm{~B}-25 \mathrm{~s}$ per shift. Changes in operations could result in significant variations in the total number of B-25s being processed and or staged for processing in the cell at any one time. In any event this would be significantly fewer B-25s than one of E-Area Vault cells would contain when it is filled with B-25s prior to final disposition. Therefore, in an effort to account for the variation in inventory in the cell where the WSF would be located and to demonstrate the worst case consequences, the accident evaluated involves fire in a cell filled with B-25s. An E-Area Vault cell can hold up to 100 times the number of B-25s that would be processed at any one time in the WSF. Using the dose-to-risk conversion factors of $4.0 \mathrm{E}-4$ and $5.0 \mathrm{E}-4$ (onsite and offsite, respectively) LCFs per person-rem (56 FR 23363), a fire that would consume a cell completely full of B-25s would result in 0.01 LCFs onsite and 0.04 LCFs offsite. The actual inventory that would be present in the WSF would be approximatly 100 times less than the inventory analyzed here. Therefore, a release of the entire inventory in the WSF would result in no on-site or off-site LCFs.

\subsection{Decontamination and Decommissioning}

When the WSF is no longer needed, the containment enclosures and volume reduction equipment would either be decontaminated for reuse in a future location or dismantled and disposed of as LLW. With the completion of the WSF D\&D activities, the vault space would be avaliable for further use.

\subsection{Environmental Consequences of the Alternatives}

The No-Action case is to send some LLW offsite for sorting, shredding, and compaction. The balance would be disposed in E-Area Vaults. This is the part of moderate treatment configuration (Alternative B) selected and analyzed in the WMEIS (DOE, 1995a) as the preferred alternative and implemented in the ROD issued on September 22, 1995. It was also the subject of the Off-Site Volume Reduction of Low-Level Radioactive Waste EA (DOE, 1995b) and its associated FONSI. The risks in this alternative result mainly from the transportation of the B-25s to an off-site facility and the return of processed waste to SRS. In the analysis, the environmental consequences were found to be acceptable (DOE, 1995a, 1995b).

Sending all LLW unsorted to E-Area Vaults was also analyzed in the WMEIS (DOE, 1995a) and Off-Site Volume Reduction of Low-Level Radioactive Waste EA (DOE, 
1995b). The major consequence was the inefficient use of vault space resulting in the need to build, operate, and maintain additional vault space with resulting impacts on the environment (DOE, 1995a, 1995b).

\subsection{Cumulative Impacts}

There would be no measurable impacts to the local economy as a result of the proposed action. The change in site usage of domestic and potable water would not be measurable. The change in volume of sanitary wastewater treated would not be measurable. There is expected to be no measurable impact on the site streams and wetlands as a result of this action. The WSF would not impact the amount of vehicle traffic associated with activities at the site.

The cumulative impacts of the disposition of the WSF process outputs (Appendix B) are analyzed in and bounded by existing NEPA documents; WMEIS (DOE, 1995a), CIF EA (DOE, 1992), Off-Site Volume Reduction of LLW EA (DOE, 1995b), and Waste Management Activities for Groundwater Protection EIS (DOE, 1987).

\subsection{REGULATORY AND PERMITTING PROVISION CONSIDERATIONS}

\subsection{National Environmental Policy Act of 1969, as Amended (42 USC 4321 et seq.)}

This EA has been prepared in compliance with the NEPA of 1969, as amended, and the Council on Environmental Quality Regulations for Implementing NEPA (40 CFR Parts 1500-1508), DOE Regulations (10 CFR Part 1021), and DOE Order 451.1A. NEPA, as amended, requires "all agencies of the Federal Government" to prepare a detailed statement on the potential environment effects of proposed "major Federal actions significantly affecting the quality of the human environment." This EA has been prepared to comply with NEPA and to assess the significance of the environmental effects of the WSF.

\subsection{Clean Air Act}

The Clean Air Act establishes a national program to protect air quality and regulates sources of air pollution. Requirements include permits, emissions and operating standards, and monitoring. Air emissions are regulated by EPA in 40 CFR 50-99. In particular, radionuclide emissions are regulated under National Emission Standard for Hazardous Air Pollutants (NESHAP) program (40 CFR 61).

\subsection{Waste Shipment Regulations}

Off-site shipment of LLW must comply with Department of Transportation (DOT) regulation 49 CFR 173 for shipments of radioactive materials and any applicable state 
regulations for transportation of radioactive materials. The carrier must pass pre-trip inspection checklists in conformance with requirements of the Federal Motor Carrier Safety Regulations (49 CFR 390-399). In addition, any empty shipping containers would as much as reasonably practicable be in compliance with 49 CFR 173.427 (a)-(e). On-site shipments must comply with DOE Orders.

\subsection{Additional Regulatory, Permitting Provisions, and Site Requirements}

Waste accepted at E-Area Vaults must be in compliance with Site E-Area Vault Waste Acceptance Criteria in the WSRC 1S Manual (WSRC, 1993) and the DOE Radiological Control Manual (DOE, 1994b). Off-site shipments would have to comply with any applicable NRC and state radioactive materials licenses. 


\subsection{REFERENCES}

Batson, W.T., J.S. Angerman, and J.T. Jones, 1985. Flora of the Savannah River Plant: An Inventory of the Vascular Plants on the Savannah River Plant, South Carolina, Savannah River Plant National Environmental Research Plant Program, Aiken, South Carolina.

Brooks, R.D., 1993. Savannah River Archaeology Research Program, South Carolina Institute of Archaeology and Anthropology, University of South Carolina, Columbia, South Carolina, personal communication with L.S. Moore, Halliburton NUS Corporation, Aiken, South Carolina, "SRS Archeological Sites and National Register of Historic Places Status," November 15, 1993.

Brooks, R.D., 1994. Savannah River Archaeology Research Program, South Carolina Institute of Archaeology and Anthropology, University of South Carolina, Columbia, South Carolina, personal communication with L.S. Moore, Halliburton NUS Corporation, Aiken, South Carolina, "SRS Archeological Sites and National Register of Historic Places Status," January 24, 1994.

DOE (Department of Energy), 1987. Final Environmental Impact Statement, Waste Management Activities for Groundwater Protection, Savannah River Site Aiken, South Carolina, DOE/EIS-0120, Savannah River Operations Office, Aiken, South Carolina.

DOE (Department of Energy), 1990. Final Environmental Impact Statement, Continued Operation of K-, L-, and P-Reactors, Savannah River Site Aiken, South Carolina, DOE/EIS-0147, Savannah River Operations Office, Aiken, South Carolina.

DOE (Department of Energy), 1992. Environmental Assessment, Consolidated Incineration Facility, Savannah River Site, DOE/EA-0400, Office of environmental Restoration and Waste Management, Savannah River Site, Aiken, South Carolina.

DOE (Department of Energy), 1994a. Final Supplemental Environmental Impact Statement, Defense Waste Processing Facility, DOE/EIS-0082-S, Savannah River Operations Office, Savannah River Site, Aiken, South Carolina.

DOE (Department of Energy), 1994b. DOE Radiological Control Manual, Savannah River Operations Office, Savannah River Site, Aiken, South Carolina.

DOE (Department of Energy), 1995a. Final Environmental Impact Statement Waste Management, DOE/EIS-0217, Savannah River Site, Aiken, South Carolina. 
DOE (Department of Energy), 1995b. Environmental Assessment for the Off-Site Volume Reduction of Low-Level Waste from the Savannah River Site, DOE/EA-1061, Savannah River Site, Aiken, South Carolina.

Jaegge, W. T. , N. L. Kolb, B. B. Looney, I. W. Marine, O. A. Towler, and J. R. Cook, 1987. Environmental Information Document: Radioactive Waste Burial Grounds, DPST-85-694, E. I. duPont de Nemours and Co., Savannah River Laboratory, Aiken, South Carolina.

NUS (Halliburton NUS Environmental Corporation), 1991. American Indian Religious Freedom Act (AIRFA) Compliance at the Savannah River Site, Aiken, South Carolina.

NUS (Halliburton NUS Environmental Corporation), 1997. Socioeconomic Characteristics of Selected Counties and Communities Adjacent to the Savannah River Site, Halliburton NUS Corporation, Aiken, South Carolina.

Stephenson, D. E. and A. L. Stieve, 1992. Structural Model of the Basement in the Central Savannah River Area, South Carolina and Georgia, WSRC-TR-92120, Westinghouse Savannah River Company, Aiken, South Carolina.

USDA (U.S. Department of Agriculture), 1990. Soil Survey of Savannah River Plant Area Parts of Aiken, Barnwell, and Allendale Counties, South Carolina, Soil Conservation Service, Washington, D.C.

Wike, L. D., R. W. Shipley, A. L. Bryan, Jr., J. A. Bowers, C. L. Cummins, B. R. del Carmen, G. P. Friday, J. E. Irwin, J. J. Mayer, E. A. Nelson, M. H. Paller, V. A. Rogers, W. L. Specht, and E. W. Wilde, 1994. SRS Ecology: Environmental Information Document, WSRC-TR-93-496, Westinghouse Savannah River Company, Savannah River Site, Aiken, South Carolina.

WSRC (Westinghouse Savannah River Company), 1989. Reactor Operation Environmental Information Document. Volume III: Meteorology, Surface Hydrology, Transport and Impacts (U), WSRC-RP-89-817, Westinghouse Savannah River Company, Aiken, South Carolina.

WSRC (Westinghouse Savannah River Company), 1993. SRS Waste Acceptance Criteria Manual, 1S Manual, Westinghouse Savannah River Company, Aiken, South Carolina.

WSRC (Westinghouse Savannah River Company), 1995. Safety Analysis Report Savannah River Site, WSRC-SA-19, Rev. 0, Westinghouse Savannah River Company, Aiken, South Carolina. 
WSRC (Westinghouse Savannah River Company), 1996. Preliminary Evaluation of Site Waste Streams for Acceptability of Waste Shipments to SEG, ESH-HPT96-0135, Westinghouse Savannah River Company, Aiken, South Carolina.

WSRC (Westinghouse Savannah River Company), 1997a. SRS Urban Wildlife; Environmental Information Document, WSRC-TR-97-0093, Westinghouse Savannah River Company, Aiken, South Carolina.

WSRC (Westinghouse Savannah River Company), 1997b. Alternative Evaluation for Low Level Waste Sorting Facility, G-ESR-E-00003, Rev 0, Westinghouse Savannah River Company, Aiken, South Carolina.

WSRC (Westinghouse Savannah River Company), 1997c. CAP88 Modeling; Waste Segregation Facility in E-Area, SRT-EST-97-457, Westinghouse Savannah River Company, Aiken, South Carolina.

WSRC (Westinghouse Savannah River Company), 1997d. Dose Rate Calculations for Second Sort Project, SWD-WGS-97-0137, Westinghouse Savannah River Company, Aiken, South Carolina.

WSRC (Westinghouse Savannah River Company), 1997e. Savannah River Site Environmental Report for 1996, WSRC-TR-95-076, Westinghouse Savannah River Company, Savannah River Site, Aiken, South Carolina. 


\section{Appendix A FACILITY DESCRIPTIONS}

Some of the equipment and facilities mentioned in this EA were presented in the SRS Waste Management EIS (DOE, 1995a) and the CIF EA (DOE, 1992). They are discussed here to aide in the understanding of the overall LLW disposal process at SRS.

\section{E-Area Vault Description}

\section{OBJECTIVE:}

E-Area Vaults provide disposal and storage for solid, low-level, nonhazardous wastes to support continuing SRS operations. As presently planned, the facility would include three types of structures for four designated waste categories: low-activity waste vaults would receive one type of waste; the long-lived waste storage buildings would accept wastes containing isotopes with half-lives that exceed the performance criteria for disposal; a third type of structure divided in two parts, intermediate-level nontritium vaults and intermediate-level tritium vaults, would receive two categories of waste.

DOE Order 5820.2A, "Radioactive Waste Management," establishes performance criteria for the disposal of LLW. A radiological performance assessment is required to ensure that the waste inventory and the proposed disposal method provide reasonable assurance that the performance objectives would be met. The radiological performance assessment projects the migration of radionuclides from the disposed waste to the environment and estimates the resulting dose to people. DOE has completed the radiological performance assessment for E-Area Vaults and has incorporated the results into the waste acceptance criteria to define maximum radionuclide inventory limits that are acceptable for disposal. DOE would construct additional vaults of the current designs or alternate designs that can be demonstrated to achieve the performance objectives.

\section{DESCRIPTION:}

The Waste Management Activities for Groundwater Protection Final Environmental Impact Statement (DOE, 1987) and it's ROD (53 FR 7557) identified vaults as one of several project-specific technologies considered for new disposal/storage facilities for low-level radioactive waste. One of the actions was construction of a new "vault design" low-level radioactive waste facility in E-Area adjacent to the existing LLW Disposal Facility.

E-Area Vaults are centrally located between the two chemical separation areas (F-Area and H-Area) near the center of SRS and consist of three types of facilities. Below-grade concrete vaults (referred to as intermediate-level waste vaults) would be used for disposal of containerized intermediate-activity tritiated and nontritiated waste. Above-grade concrete vaults (referred to as low-activity waste vaults) would be used for disposal of containerized low-activity waste. On-grade buildings (referred to as long-lived waste 
storage buildings) would be used for storage of containerized spent deionizer resins and other long-lived wastes.

The low-activity waste vaults are concrete structures approximately 200-meters (643-feet) long by 44-meters (145-feet) wide by 8-meters (27-feet) deep. Each vault contains 12 cells with approximately 30,500 cubic meters $\left(1.07 \times 10^{6}\right.$ cubic feet) of usable waste disposal capacity. End, side, and interior walls of each module are 0.61-meter (2-feet) thick. The low-activity waste vault walls are structurally mated to the footers, and the floor slabs are poured between and on top of the footers.

The low-activity waste vaults have a permanent 41-centimeter (16-inch) thick, poured-in-place concrete roof to prevent the infiltration of rainwater and are constructed on poured-in-place concrete pads with sidewalls. When the vaults are filled to capacity, a closure cap would be used to cover the concrete roof to further reduce the infiltration of water. Each cell within the vault has a means of collecting and removing water that enters the vault.

Low-activity waste to be disposed of would be containerized and stacked using an extendible boom forklift. Low-activity waste would be packaged in various approved containers such as steel boxes and DOT-approved drums. Packaging and stacking would be similar to the engineered low-level trench operation for low-activity waste.

Each low-activity waste vault would be closed in stages. Individual cells would be closed, then the entire vault area would be closed. Low-activity waste vault final closure consists of placing an earthen cover with an engineered clay cap over the entire vault area.

\section{Consolidated Incineration Facility (CIF)}

\section{OBJECTIVE:}

The CIF would provide incineration capability for a wide range of combustible hazardous, mixed, and low-level wastes. This facility represents the consolidation of several separate SRS incineration initiatives:

- a hazardous waste incinerator that would have provided incineration capability for SRS solid and liquid hazardous wastes

- a DWPF benzene incinerator that would have provided dedicated incineration capability for the benzene generated by the high-level waste processing activities at the DWPF

- a hazardous waste incinerator upgrade that would accept SRS solid and liquid mixed wastes as well as solid and liquid nonhazardous, radioactive wastes 


\section{DESCRIPTION:}

Incineration was selected because it was the Resource Conservation and Recovery Act (RCRA)-specified technology or the best demonstrated available technology for many SRS hazardous and mixed wastes, and it would provide cost-effective volume reduction for LLW. The CIF would include processes to stabilize the incinerator solid waste residues (ash) and offgas-scrubber-blowdown liquid with cement into a form known as ashcrete for on-site disposal in accordance with applicable regulations. A permit application to include stabilization of the incinerator offgas-scrubber-blowdown liquid in the ashcrete process has been approved by state regulatory agencies.

Under the Federal Facility Compliance Act, DOE was required to develop site-specific plans (SRS Site Treatment Plan) to treat mixed wastes to the standards established under RCRA. Incineration is required by the EPA Land Disposal Restrictions regulations for the treatment of certain SRS mixed wastes.

The CIF main process building (Building $261-\mathrm{H}$ ) includes areas for solid waste receipt; solid waste handling; a rotary kiln incineration system, including incinerator ash removal and treatment, and offgas cleaning; and the necessary control room and support service facilities. A system to solidify incinerator ash and offgas-scrubber-blowdown is installed.

The CIF would process both liquid and solid wastes. Solid waste would be delivered in cardboard boxes manually loaded onto a conveyor. The boxes would pass through a portal monitor to determine if the radiation rate of the box contents was below the maximum CIF waste acceptance criteria of 10 millirem per hour at 76.2 millimeters (3 inches). The boxes would be $\mathrm{x}$-rayed to ensure that materials unacceptable to the incineration process were not present. Waste boxes would be assayed to ensure that their curie content was in agreement with the waste manifest. Boxes would be stored on the conveyor system before being fed to the incinerator.

Liquid waste would be transported to the CIF by various methods. Radioactive organic waste (benzene) would be piped directly from the DWPF for incineration. Other liquid wastes would be transported in carboys, drums, or tanker trucks to the CIF tank farm which consists of five tanks: a 25-cubic meter (6,500-gallon) aqueous waste tank, two 16-cubic meter (4,200-gallon) blend tanks, a 25 -cubic meter (6,500-gallon) spare tank, and a 48-cubic meter (12,600-gallon) fuel oil tank. Dikes (secondary containment) to contain accidental spills would be provided around the waste tanks, fuel oil tank, and the truck unloading pads. Liquids collected in sumps in the diked areas would be analyzed for contamination. If contamination was found, the liquid would be pumped into the aqueous waste tank for processing in the incinerator. Liquid wastes from the tank farm would be blended to provide a solution with a heating value, viscosity, and an ash and chlorine content that would achieve stable combustion in the rotary kiln. Aqueous waste may be blended with other liquids for incineration or be evaporated in the incinerator, depending on the heating value of the liquid and free water content. Additional CIF 
related components would include a propane storage tank and two standby diesel generators.

The incinerator system consists of a rotary kiln primary incineration chamber and a secondary combustion chamber. The system is designed to ensure a 99.99 percent destruction and removal efficiency for each principle organic hazardous constituent in accordance with RCRA regulations.

The secondary combustion chamber offgas (exhaust) would be treated by a wet scrubbing system for acid gas control and particulate removal to meet environmental regulations. The offgas system consists of a quench system for temperature reduction; a free-jet scrubber; a cyclone separator; a mist eliminator; a reheater; high-efficiency particulate air filters; induced draft fans; and an exhaust stack. The offgas wet scrubber liquid chemistry would be controlled to maintain suspended solids and chlorine concentration limits. Concentration limits would be maintained by emptying and refilling the offgas wet scrubber storage tank. The scrubber liquid blowdown would be solidified in cement, in the same manner as the incinerator ash, at the ashcrete stabilization unit.

High-efficiency particulate air filters are provided for the container handling kiln feed, ashout areas exhaust vents, and the kiln seal shroud exhaust. Stack monitoring equipment is installed to monitor the discharge of chemical and radiological materials.

The CIF is expected to achieve a net volume reduction of $20: 1$ for low-level job-control waste and other types of solid waste, and $40: 1$ for liquid waste, even considering the increase in volume due to secondary waste stabilization. The mechanical design utilization is based on a combination of waste throughput, waste forms, and material handling requirements to physically accommodate waste material feed. The thermal utilization is based on the amount of heat that can be safely and effectively dissipated from the incinerator.

Mechanical utilization limit is the hourly throughput rating. The annual operating capacity of the CIF for liquid waste would be approximately 4,630 cubic meters (1.63E5 cubic feet) per year at 70 percent attainment and for solid waste, approximately 17,830 cubic meters (6.3E5 cubic feet) per year at 50 percent attainment. The incinerator liquid-waste-feed-system design is based on a high heating value (i.e., organics) liquid waste flow rate of 312 kilograms per hour ( 687 pounds per hour) and low heating value (i.e., aqueous) liquid waste flow rate of 431 kilograms per hour ( 950 pounds per hour). The incinerator is designed to incinerate an annual average of 329 kilograms per hour (720 pounds per hour) of solid waste, based on the total heating value and ash content of the solid waste.

Thermal utilization limits are expressed in terms of British thermal units (BTU) (amount of energy required to raise the temperature of 1 pound of water from 58.5 degrees Fahrenheit to 59.5 degrees Fahrenheit) per hour. The maximum feed rate is determined by the combined heat release of the waste forms and auxiliary fuel oil. The maximum 
thermal release rating for the CIF rotary kiln system is limited to about 13 million BTUs per hour. The maximum thermal release rating for the secondary combustion chamber is about 5 million BTUs per hour. The CIF is limited to an approximate thermal capacity of 18 million BTUs per hour.

DOE has received approval to operate the CIF to segregate and incinerate listed hazardous and mixed wastes separately from characteristic-only hazardous wastes and nonhazardous wastes. It is assumed that treating hazardous, mixed, and mixed alpha waste in the CIF would result in 70 percent secondary waste disposal in RCRA-permitted disposal vaults and 30 percent secondary waste disposal in shallow-land disposal. It is also assumed that low-level and non-mixed alpha waste treatment would result in 100 percent secondary waste disposal in shallow-land disposal.

\section{Compactors}

\section{OBJECTIVE}

Compactors provide a method to reduce the volume of LLW, thereby increasing disposal capacity.

\section{DESCRIPTION}

\section{In-box Compactor}

Low-activity waste has been compacted onsite in several different LLW compactors in either H-, M-, or L-Area. The H-Area compactor, an enclosed steel-box-container (B-25) compactor with vented high efficiency particulate air filter systems (HEPA), may be moved and utilized at the WSF. The H-Area compactor has received job-control waste from separations, waste management, reactors, tritium, and DWPF facilities. Engineered features and administrative controls associated with the box compactor include containment areas, HEPA-filtered exhaust system, constant air monitors, and a remote operation in which the operator is not in the direct compaction area.

Compactor personnel manually inspect each 533-mm (21-in) box and then load them into the B-25 being compacted via the upper handling door. The upper door is lowered after the B-25 has been fully loaded and the compacting ram is lowered. The actual compaction is performed from the control panel located in the compactor area. After compaction, the compactor ram is raised before the material handling door is opened. This ensures that any possible contaminated air is cycled through the HEPA system before the door is opened. Cardboard boxes containing LLW are manually added to the B-25 and the contents recompacted. This process is repeated until the compactor compression efficiency limit is reached. The box compactor compression efficiency ratio is 4 to 1 . Full B-25s are removed from the compactor with forklifts. The lid is secured outside of the compactor area. The box is surveyed for contamination and radiation levels prior to release and transfer to the E-Area Vaults. 
lid is secured outside of the compactor area. The box is surveyed for contamination and radiation levels prior to release and transfer to the E-Area Vaults.

\section{Drum Supercompactor}

A drum supercompactor is designed and operated much like an in-box compactor except that the waste is placed in drums instead of $\mathrm{B}-25 \mathrm{~s}$. The compaction pressure is also higher, on the order of 8,896 to 22,241 kilonewtons (1,000 to 2,500 tons). A filled drum is placed into the supercompactor and the entire drum compacted via application of at least $8,896 \mathrm{kN}(1,000$ tons $)$ of force to reduce the drum into a puck shaped object. The volume reduction ratio achieved will range from $3: 1$ to $12: 1$, with an average of about 5:1 depending on drum contents. The individual pucks will be removed from the supercompactor and placed into larger drums or B-25s and disposed of in the E-Area Vaults. 


\section{Appendix B TREATMENT PROCESS FLOW}

It is assumed that all of the low-activity job control waste generated each year as well as legacy B-25s from E-Area Vaults would be transferred to WSF which would perform various volume reduction and sorting steps including sorting, segregating, shredding, boxed waste compaction, and drummed waste compaction. The following process streams are expected:

- 25 percent compacted (in-box compactor or drum supercompactor)

- 50 percent as-is or reduced in size and repackaged for treatment at the CIF

- 15 percent salvageable materials for decontamination and free-release

- 10 percent miscellaneous non-combustible, non-compactable and other waste repackaged for further evaluation/disposition

The projected throughput is estimated at 4500 B-25 boxes annually for single-shift operation. Three-shift operation of the facility is possible, in which case, up to 7000 boxes annually could be processed. The process flow and quantities are depicted in Figure B-1.

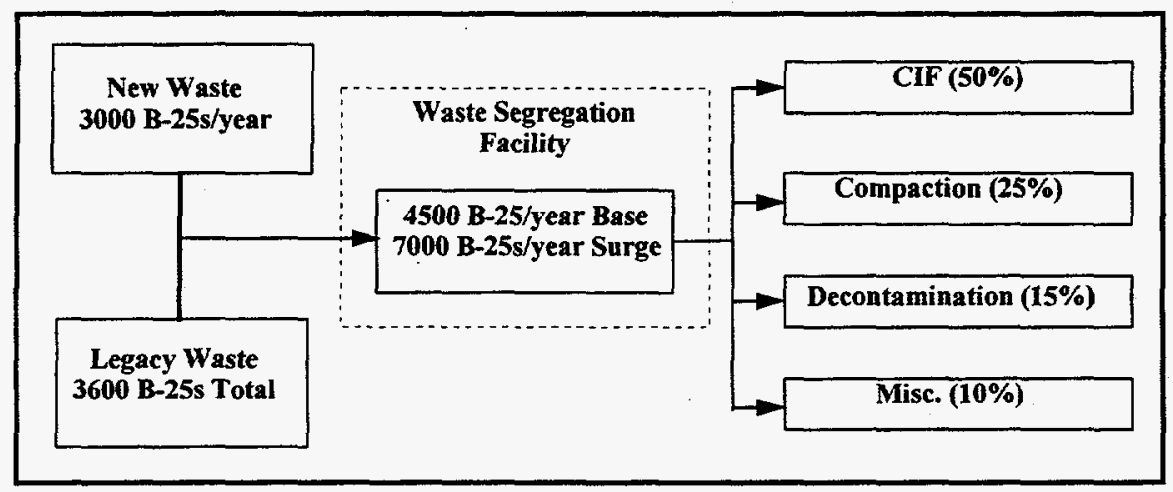

Figure B-1. Treatment Process Flow 


\section{GLOSSARY}

B-25 Box. A 2.55-cubic meter (90-cubic feet) steel box used to contain radioactive waste for disposal.

E-Area Vault. Project which consists of several types of facilities (i.e., below-grade concrete structures, on-grade concrete structures within excavated areas) that will dispose of designated waste types (low-activity, intermediate-level tritiated and nontritiated, and long-lived waste) of LLW.

Fission Products. Nuclei from fission of heavy elements (primary fission products); also, the nuclei formed by the decay of primary fission products, many of which are radioactive.

Groundwater. The supply of fresh water under the Earth's surface.

Person-rem. The radiation dose to a given population; the sum of the individual doses received by a population segment.

rad. Unit of absorbed dose deposited in a volume of material.

rem. Unit of dose equivalent (absorbed dose in rads $\mathrm{x}$ the radiation quality factor). Dose equivalent is frequently reported in units of millirem (mrem) which is one-thousandth of a rem.

Transuranic. Alpha-emitting elements heavier than uranium.

Vadose Zone. Soil zone located above the water table. 


\section{Acronyms and Abbreviations:}

\section{Acronyms}

BTU British Thermal Unit

CERCLA Comprehensive Environmental Response, Compensation, and Liability

Act

CFR Code of Federal Regulations

CIF Consolidated Incineration Facility

DBA Design Based Accidents

DOE Department of Energy

DOT Department of Transportation

DWPF Defense Waste Processing Facility

D\&D Decontamination and Decommissioning

EA Environmental Assessment

EIS Environmental Impact Statement

EPA Environmental Protection Agency

FFA Federal Facility Agreement

FONSI Finding of No Significant Impact

LCF Latent Cancer Fatalities

LLW Low-Level Radioactive Waste

NEPA National Environmental Policy Act

NESHAP National Emission Standard for Hazardous Air Pollutants

NPDES National Pollutant Discharge Elimination System

RCRA Resource, Conservation, and Recovery Act

ROD Record of Decision

SCDHEC South Carolina Department of Health and Environmental Control

SRS Savannah River Site

WSF Waste Segregation Facility

Abbreviations for Measurements

$\begin{array}{ll}\mathrm{ft} & \text { Feet } \\ \mathrm{gal} & \text { Gallon } \\ \mathrm{ha} & \text { Hectare } \\ \mathrm{hr} & \text { Hour } \\ \mathrm{km} & \text { Kilometer } \\ \mathrm{kN} & \text { Kilonewton } \\ \mathrm{L} & \text { Liter } \\ \mathrm{m} & \text { Meter } \\ \mathrm{mm} & \text { Millimeter } \\ \mathrm{mi} & \text { Mile }\end{array}$

